\title{
Obituary
}

\section{Dr. Herbert H. Thomas, F.R.S.}

$\mathrm{T}$ HE sudden death on May 12 of Dr. Herbert H. Thomas, petrographer to H.M. Geological Survey, at the early age of fifty-nine years, has caused a sad gap in the ranks of British geologists, and deprived a large circle of a warm friend and helpful adviser. To brilliant academic attainments he added further lustre during his subsequent geological career. His wide interests and accurate knowledge were readily placed at the service of those who consulted him, and his sympathetic nature made him an unusually large circle of friends. To know Thomas was to love him.

Educated at Exeter School, where his family then lived, Thomas entered Sidney Sussex College. In due time he obtained a first class in Part $I$ and in Part II of the Natural Sciences Tripos; was awarded the Harkness Scholarship (1898) and the Sedgwick Prize (1906). In 1898-1901 he acted as assistant to Prof. W. J. Sollas at Oxford. In 1901 he was appointed geologist on H.M. Geological Survey and was assigned to the South Wales district; just at the time when the classic district of Llandeilo was about to be entered by the surveyors.

Thomas, trained at Cambridge, had the good fortune to be associated with T. C. Cantrill, who was a pupil of Lapworth at Birmingham. Both these officers had been imbued with the work of Lapworth and of Marr and others of the Cambridge School on the Lower Palæozoic rocks. At the same time, Sir Jethro Teall had beenappointed director of theSurvey. The conditions were therefore exceptionally favourable to the adoption by the Geological Survey of Lapworth's threefold classification of those rocks which is now in universal use in place of Murchison's classification, previously used on its maps and in its memoirs. Thomas remained on the field staff until the completion of South Wales in 1911, when he was appointed petrographer-a post for which his training and interests in mineralogy eminently fitted him. $\mathrm{He}$ retained, however, a keen interest in the older rocks of South Wales, and frequently returned to attack their problems. Several papers appeared in the Quarterly Journal of the Geological Society jointly with O. T. Jones and with A. H. Cox.

In later years, Thomas's official duties brought him into intimate contact with the officers of the Scottish branch of the Geological Survey who were engaged in examining the Tertiary igneous rocks of the west of Scotland. When he was president of Section C of the British Association in 1927, he gave a brilliant address on the Tertiary volcanic history of north-west Britain. His interest in mineralogy, which had begun in his youth among the mine-heaps of Cornwall and Devon, was maintained throughout his career, as instanced by his valuable contributions on the minerals of the Trias of the south-west of England and papers on minerals and optical apparatus which were contributed to the Mineralogical Society, of which he was an active member.

Largely through association with T. C. Cantrill, Thomas took a keen interest in prehistory, and his wide knowledge of igneous rocks and their distribu. tion was readily placed at the disposal of many visitors to the Geological Survey offices in Jermyn Street, who brought for investigation, stones, axes and other objects of archæological interest. By his fortunate acquaintance in the field with the igneous rocks of Pembrokeshire, he was able conclusively to solve the mystery of the blue-stones of Stonehenge, which had previously been assigned to many and diverse sources, and to show that they had been derived from a small area surrounding Carn Meini in the Precelly range.

Thomas was awarded the Murchison Medal in 1925 by the Geological Society of London, of which he was secretary from 1912 until 1922 and vice-president from 1922 until 1924. He also served on the Council of the Mineralogical Society. He was elected to the Royal Society in 1927, and at the time of his death was on the Council. $\mathrm{He}$ is survived by his widow, one son and one daughter.

\section{Mr. J. E. QUibelL}

THE death is announced of James Esward Quibell, well known as an Egyptologist, at the age of sixtyeight years. Born at Newport, Shropshire, he was educated at the Newport Grammar School and at Christchurch, Oxford, of which he was an exhibitioner. After taking honours in Classical Moderations and the Final School of Natural Science, he engaged for a time in teaching; but travel in Egypt attracted him to archæology. He joined Prof. Flinders Petrie, assisting in the excavation of Coptos, Nagada, El $\mathrm{Kab}$, Hierakonpolis and other sites. After a brief period of study at Berlin, he was appointed to the Catalogue Commission of the Egyptian Museum, Cairo, and in 1899 became an inspector in the Egyptian Antiquities Department.

Quibell conducted excavations in Upper Egypt and at Saqqara for a number of years and then in 1913 was made keeper of the Egyptian Museum, a post which he held until his retirement in 1925, although for the last two years of his tenure he acted as Secretary-General to M. Lacau, Director-General of Antiquities. Two years later he suffered serious loss in the death of his wife, a daughter of Principal Pirie of the University of Aberdeen, herself a distinguished archæologist. Notwithstanding the break in his life occasioned by this loss, he continued to pursue his archæological studies in Egypt almost to the end. He leaves behind him a record of sound and methodical work which has not always been so widely or so fully recognised as it deserves. 